EUROPEAN UNIVERSITY INSTITUTE, FLORENCE DEPARTMENT OF HISTORY AND CIVILIZATION

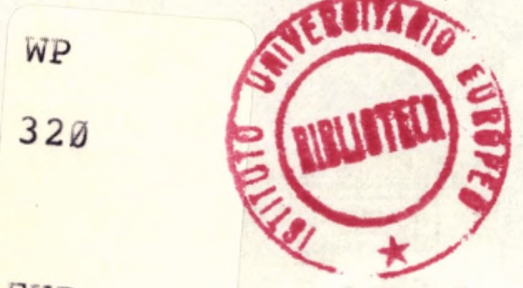

EUR

EUI WORKING PAPER No. $87 / 314$

MODELS OF EQUALITY FOR WOMEN:

THE CASE OF STATE SUPPORT FOR CHILDREN

IN TWENTIETH CENTURY BRITAN

by

Jane LEWIS

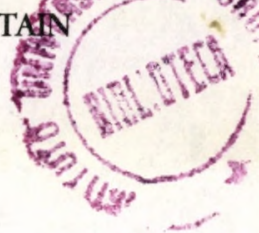

BADIA FIESOLANA, SAN DOMENICO (FI) 
This paper should not be reproduced in whole or in part without prior permission of the author

(C) Jane Lewis

Printed in Italy in October 1987

European University Institute

Badia Fiesolana

I-50016 San Domenico (Fi) 
Jane Lewis

MODELS OF EQUALITY FOR WOMEN: THE CASE OF STATE SUPPORT FOR CHILDREN IN TWENTIETH CENTURY BRITAIN*

The campaign for family allowances and its pre-World War I variant, mothers's endowment, was initiated and led by feminists. Today, state payments in respect of children remain an important issue for feminists. This is because provision for children raises two fundamental issues pertaining to the gender division in modern industrial societies: first, that of the division of resources within the family, and second, the relationship between wages and work and the support of and care for dependent family members. The classic surveys of poverty in the late nineteenth century by Booth and Rowntree, and in the late twentieth century by Townsend, all failed to examine carefully the way in which resources were divided after they entered the family (1). Throughout the twentieth century this concern has been the prerogative of feminists, concerned about the relative poverty of both wives and children. Eleanor Rathbone, who formed the Family Endowment Society in order to campaign for family allowances in 1917, and who was in Parliament as an Independent MP to see the passage of the Family Allowances Act in 1945, pointed out that the male wage was intended to provide a reward for individual effort and not necessarily also to meet the needs of a wife and unspecified number of children. She also emphasised that women's work as wives and mothers was not rewarded and that a disproportionate amount of child poverty resulted from these two factors. In her initial formulation, family allowances were intended to provide an allowance for children and a wage for mothers (2).

This paper seeks first to locate the debate ove family allowances in the context of (a) the assumptions of social investigators and policymakers about family relationships and about the proprer role of the state in relation to the family, and (b) the social reality of women's position in 
the family and the meaning women gave to it. It may be argued that the feminist case for family allowances, which emerged in the years before world War I and was formalised chiefly by Rathbone in the early 1920s, accurately reflected the aspirations of early twentieth century women and challenged the direction of state policy in respect to social security provision. However, during the 1930s, the feminist case for allowances became submerged and the idea of providing a wage for mothers was lost, as the proposal became the focus of a wide variety of political groups who believed that family allowances would achieve widely differing social goals, from population growth to the vertical redistribution of wealth. This part of the story is accorded less space here because it has been told in some detail by John Macnicol, who has concluded that no one group can be credited with the passage of the family allowances legislation (3). Rather, government was converted to the necessity of introducing allowances in order to hold down wages during a period of war-time inflation.

Reflecting this final reason for their introduction, family allowances were never sufficient to cover the costs of a child. In 1977 allowances and child tax credits were merged into a payment called child benefit, which, like its predecessor, was (after considerable Parliamentary debate) paid directly to the mother. The question of how to pay and care for children still provides one of the most challenging questions feminists can put to economists (4) and requires that we think about possible models for achieving sexual equality in society. The final part of the paper suggests that the feminist campaign for family allowances during the first half of the twentieth century sought to use the state to mediate unequal outcomes in terms of the division of resources within the family, without challenging the allied issue of the division of work, paid and unpaid. When the idea of family allowances was first mooted, in the years before the First World War, such an idea of state intervention was radical and the acceptance of the sexual division of labour in and outside the home reflected the reality of women's position and the hardship that would be imposed on working class women if they had to undertake full-time work as well as undergo frequent 
pregnancy and do hard household labour. The position of late twentieth century women is very different. Family size is considerably smaller and household labour easier, and the proportion of married women working outside the home was increased sixfold since World War II. Child benefit and the campaign to increase its value continues to represent a valid response to the problem of the unequal division of resources within the family, especially because it is paid to women. However, it does not address inequalities in the division of paid and unpaid work and indeed may be argued to encourage the assumption that caring for children is 'women's work'. In the circumstances of the late twentieth century therefore, it may no longer accurately reflect feminists' conception of equalify.

THE EARLY DEBATE: STATE ASSUMPTIONS AND WOMEN'S REALITY

During the late nineteenth and early twentieth centuries, the ideology of 'separate spheres' with men taking their place in the public world and women remaining in the private sphere of the family was firmly supported by Victorian social and medical science (5) and informed social policymaking. It was the position of middle class women that most closely conformed to prescribed behaviour. Prior to World War I neither single nor married women of the middle class engaged in paid labour with the result that marriage was, as the feminist Cicely Hamilton bitterly remarked in 1909, their only 'trade' (6). Working class women, both single and married, had in contrast always worked outside the home. In the case of married women, their paid labour was often casual, consisting of a day's charring or hawking fruit as and when the dictates of the family economy demanded it. As such, it tended to escape the attentions of the census enumerators. However women's contribution to the family economy was crucial. As Elizabeth Roberts has remarked, $1 / 6 \mathrm{~d}$ so earned could feed a family of three for two days in the years before World War I (7).

Irrespective of the different behaviour of women in different social classes, policymakers legislated on matters affecting primarily poor 
families as if the ideology of separate spheres was actually reflected in the behaviour of all women. The 'ought' regarding women's role in society was thus conflated with the 'is'. Middle class social investigators were in no doubt but that the fundamentals of the male breadwinner family model, whereby men earned a 'family' wage and kept their dependent wives and children at home, was crucial to the well-being of society as a whole. In large part this was because such a model was believed to secure male work incentives. Helen Bosanquet, a leading member of the Charity Organisation Society whose opinions were sought regarding matters of social policy towards the poor, remarked that the male breadwinner family model was 'the only known way of ensuring with any approach to success that one generation will exert itself in the interests and for the sake of another' (8).

Thus the social policies affecting women that were developed by the Liberal Government of the years 1906-14 had two main characteristics: they treated adult women as the dependants of men and they sought to further their primary role as wives and mothers. The first was not always compatible with the second. Despite the outcry about high levels of infant mortality, wives and children were not included under health insurance legislation passed in 1911. The cost of covering 'dependants' would have been enormous, but as the debate over the provision of school meals for children (legislated in 1906) had shown, there was also grave concern about the state assuming the father's obligation to maintain (9). The 108 of married women who worked in insurable trades were covered under both health and unemployment insurance (also introduced in 1911) in their own right. But their position under national insurance was never secure. Early National Health Insurance records showed them to be experiencing a much higher-thanexpected rate of sickness, which led to charges of 'malingering' and a cut in their benefits in 1915 (10). In all probability their higher sickness rates were genuine; married women who worked full-time added paid labour to arduous domestic work and child care. Nor were married women the only group to experience high sickness rates. Miners did likewise, but it was not suggested that they suffer penalty. Married women were singled out as 
scroungers and malingerers under health insufance and unemployment insurance because the schemes operated through the labour market and they were perceived as wives and mothers first and waged workers a poor second. Indeed in 1931, the Anomalies Act assumed that any woman leaving a job did so voluntarily (in order to return to her proper place at home) and were therefore cut off from unemployment benefit. Once in the home women's welfare became the concern of their husbands. This kind of thinking assumed that men received a 'family wage' adequate to keep a wife and children.

Social policies directed towards adult women were concerned primarily to further their welfare as mothers, but were designed to do so primarily through educational means rather than by providing transfers either in the form of cash or services. Thus the years before World War I saw a rapid increase in the numbers of child welfare clinics and health visitors employed by local authorities. Social investigators were quick to stress the important role played by working class mothers. In 1893, Henry Higgs stressed that the quality of the working wife's housekeeping was crucial and 'could throw the balance of comfort in favour of one workman whose wages are much below those of another' (11). Charles Booth believed the working class wife and mother's role to be pivotal (12). It was she who somehow made the money go round and was, in the final event, prepared to sacrifice herself for her children. The passing of the 1870 Married Women's Property Act allowed women to keep control of their own earnings and was strongly influenced by arguments that mothers were more likely than fathers to see to it that their children were fed and their school pence paid. Policymakers were prepared to give sympathetic consideration to the needs of motherhood'. But they failed to recognise the social reality of working class mothers, most of whom were not fully supported by a family wage and were not likely to be full-time wives and mothers. After all, both Booth and Rowntree's surveys of London and York in the late nineteenth century showed almost a third of the population falling below a subsistence poverty line. In these families there was no chance of women and children being supported by a male wage. Even in skilled working class families, sickness, accident 
or unemployment on the part of the male breadwinner could easily plunge a family into poverty. The letters of the respectable members of the Women's Cooperative Guild about maternity (published in 1915), are full of cases in which such misfortune has forced the wife to work, washing or sewing, up to the eve of childbirth (13). In assuming that the husband would and should maintain, policymakers neglected the real needs of mother.

If we turn to the views of working class women themselves, we find that in large measure they shared the ideal of the male breadwinner family model which bulked so large in the imagination of policymakers, but unlike the policymakers, women were only too aware that they did not have the wherewithal to carry out the work of full-time wife and motherhood effectively. They were in no danger of confusing the 'ought' with the 'is'. The acceptance of the ideal of a male breadwinner and wife and child dependants by a large number of working women can only be understood in the context of early twentieth century working class marriage, which Ellen Ross's research has shown to have consisted of a complex system of reciprocal obligations (14). At its best it may be understood as a system of economic and emotional mutual support. According to Ross, neither romantic love, nor sexual intimacy were central to working class husbands and wives, but rather each fulfilled financial obligations and performed services and activities that were sex specific. This does not mean that affection was lacking, but at the core of the working class marriage bargain was an element of 'solid calculation' (15). Women took responsibility for home and children. They expected to act, as social investigators felt they should, as the chancellors of the domestic exchequer. In return they expected their husbands to provide and tended to judge husbands by the amount and regularity of the wage they brought home. Research into the extent and causes of domestic violence in the late nineteenth century suggests that wives were tolerant of both verbal and physical abuse if they judged themselves to have neglected their housekeeping duties in some way (16). By the same token, men might be 'nagged' into handing out a larger portion of their wages. 
Women's subscription to the ideal male breadwinner family model made sense given their material context. Early twentieth century housework involved hard physical labour, water might be fetched from a communal tap five floors below, clothes had to be pounded in a dolly tub and cooking often had to be done on an open fire in an already overcrowded living room. In addition working women underwent frequent pregnancy. Women interviewed by Elizabeth Roberts in her oral history of the north west, reported that they felt sorry for any married woman who was forced to do a full-time paid job as well as look after home and family (17). This view was reflected in the writings of the (usually middle class) leaders of working women's organisations. The Women's Labour League, for example, supported the idea of a family wage in the belief that this would give working class wives more leisure (18). They added, in a manner more reminiscent of the moralising of middle class social investigators than of the women they represented, that this would allow working class wives to become better companions to their husbands during the evenings spent sitting by the hearth. Thus broad support for a family wage came from women as well as from men workers, employers, and the state. It is not part of the project of this paper to comment at length on the basis for such a shared ideal; however, accepted ideas as to women's place and capacities, in other words a shared understanding of what constituted femininity and masculinity, certainly underpinned acceptance of the family wage and the sexual division of labour that accompanied it. Above and beyond that, the interests of those supporting the family wage ideal differed profoundly. As we have seen, social investigators and policymakers were most concerned to promote male work incentives. In the case of male workers it may be suggested that they had a vested interest in securing the unpaid services of wives as well as in furthering the welfare of their families by claiming a family wage, while working women were concerned above all to make their work managable. They accepted the primacy of their role as wives and above all as mothers and were seeking both the time and the financial resources to do a good job. At significant points, then, their demands for social reform differed significantly from those of both policymakers and working class men. 
WOMEN'S CLAIMS, 1910-1924

The leaders of organisations such as the Women's Labour League (WLL), the Women's Industrial Council (WIC), the Women's Cooperative Guild (WCG) and the Fabian Women's Group (FWG) sought above all material support for working class women to make their position as wives and mothers more tenable. The FWG and the WIC saw immediately that a measure like national insurance, while grounded in assumptions relating to appropriate gender roles within the male breadwinner family model, offered little to women, and indeed 'merely intensified the regrettable tendency to consider the work of a wife and mother in her home of no money value' (19). Women's organisations did not conflate the family wage ideal with the reality experienced by working class women and they were not likely to give support to policies that did so. Working women's representatives were on the whole content to leave women's position in the labour market to be dealt with by the trade union movement, but felt that the state should step in to help wives and mothers, so many of whose husbands did not earn a family wage. Not only should the state provide education and information, but also better maternity services and cash support. Thus while accepting the sexual division of labour, women's demands ran counter to policymakers' concerns to do nothing to undermine the assumption that men provided for their families.

In the years before World War I, women's groups and individual women social reformers differed in terms of what they felt the best form of state intervention to aid mothers should be. The FWG conducted an investigation into the circumstances of a small group of women and their families in a poor area of South London and stressed the way in which the struggle to make ends meet sapped the health and strength of the wives (20). As a group they proved one of the strongest early advocates of 'mothers' endowment'. However, a suffragist and settlement worker, Anna Martin, took a rather different view (21). Martin was above all conscious of the burden imposed on mothers as a result of both the responsibilities they bore for care of home and children and their lack of ready access to financial resources. She felt 
that many other state measures taken to improve maternal and child welfare only made matters worse. For example, the Act requiring the medical inspection of school children which failed to make adequate provision for the treatment of any problems that might be discovered amounted, she believed, to an injunction to mothers 'to make bricks without straw' (22). Mothers were told what was wrong with their children without being provided with the means to do something about it, with the result that the burden of managing the household economy and making ends meet was actually increased.

Anna Martin also reported that the working class women living in houses around the settlement in which she worked were not pleased by the government's decision in 1906 to allow local authorities to provide school meals for needy children: 'The women have a vague dread of being superseded and dethroned. Each of them knows perfectly well that the strength of her position lies in the physical dependence of husband and children upon her and she is suspicious of anything that would tend to undermine this. The feeling that she is the indispensable centre of her small world is indeed the joy and consolation of her life' (23). The wives she knew objected to state provision of school meals on the grounds that it would both undermine their role and authority within the family, and their husbands' obligation to provide. In thinking the latter, the views of at least this small group of working class women, reported second hand by Martin, would seem to have had more in common with policymakers who worried about any measure that threatened male work incentives than with the male labour movement leaders who campaigned hard for the school meals legislation. Martin's solution to the problems of working class wives was for the state to legislate them a portion of their husbands' wages. She thus implicitly attributed more blame to working class men's failure to share income equally than to the inability of men to earn a family wage.

The truth of this is hard to establish. Recent historical research has tended to stress the mutual interdependency of working class husbands and wives (24); however contemporary research into the division of money within 
families has revealed that women and children tend to receive a distinctly unequal share. There is no reason to suppose that this was untrue of the early twentieth century, after all Rowntree saw fit to comment on the fact that few wives appeared to know what their husbands earned and the FWG documented the way in which husbands would usually reserve a greater or lesser amount from their wages for their own use (25). Martin's proposals were echoed by other feminists during the 1910s, but in face of evidence as to the number of men who did not earn a family wage the FWG idea that the state should take more financial responsibility for motherhood attracted more widespread support. It also served to sidestep the issue of where to apportion blame for married women's economic insecurity. Mrs. Pember Reeves, who took charge of the FWG's South London investigation, felt that 'the woman who shrinks from the feeling that her wifehood is a means of livelihood will proudly acknowledge that her motherhood is a service to the state' (26). However, by no means all men in the Labour Movement approved of the idea. Rumsay MacDonald, leader of the Labour Party, declared mothers' endowment to be 'an insane burst of individualism, under socialism mothers' and children's right to maintenance would be honoured by the family and not by the state' (27). In other words, he saw the campaign for the state endowment of motherhood to be a danger to men's claim for a family wage and an attack on one of the basic underpinnings of late nineteenth and early tweritieth century respectable working class masculinity, viz that a man should 'keep' a wife and child.

During World War I, government took up the idea of mothers' endowment in relation to the position of widows. Some American states already paid allowances to widows and in 1917 the British Local Government Board reported on the US experience (28). It found that it was the cheapest method of providing for widows with children, but government remained suspicious of any measure that failed adequately to distinguish between the deserving and the undeserving. If the state were to step in effectively to take the place of a male breadwinner, it was believed that it should reserve to itself the traditional expectations of a husband as to chaste behaviour and sound 
domestic management on the part of the female recipient of benefit. However, ensuring this would prove too great a burden of inspection and widows were left, until 1925, to the mercy of the Poor Law. However, the war-time experience provided another incentive to women's campaign for family allowances. Eleanor Rathbone, who had already studied the position of widows in Liverpool in 1913 was impressed during the war by the workings of separation allowances (29). Despite difficulties in this administration, this programme resulted in an improvement in the health of school children (measured in terms of heights and weights)(30), and although no record was kept of the physical well-being of the mothers, there were grounds to suppose that better food and freedom from financial worries had beneficial effects on mind and body.

In 1919 Rathbone became President of the National Union of Women's Suffrage Societies, the largest women's suffrage organisation and her taking up of the campaign for family allowances signalled a significant reformulation of the organised feminist movement's conception of equality for women. Under her leadership, the NUWSS (or, as it became later in 1919 after the vote was granted, the National Union of Societies for Equal Citizenship (NUSEC)) moved towards claiming what Rathbone referred to as a 'real equality for women'. By this she meant that 'the whole structure and movement of society (should) reflect in proportionate degree their (women's) experiences, their needs and their aspirations'(31). It was argued that feminists should work for reforms which reflected the reality of women's interests, rather than those which aimed to make them equal to men on men's terms. Women should be able to choose the mode of employment which suited them best, whether in the home or outside it and should receive fair recompense for it. Family allowances would provide the means of paying women a wage for their work in the home as well as giving a cash allowance for each child. Rathbone and other executive members of the NUSEC were concerned above all to end the economic dependence of married women and children, which they felt reduced them to the status of 'male luxuries' (32). Furthermore, if women and children achieved economic independence, the chief 
impediment to equal pay for women working outside the home would disappear. Men would no longer be able to claim a family wage on the grounds that they had a family to support. In practice, the Family Endowment Committee set up by Rathbone in 1917 asked for a weekly allowance of 12/6d for the mother, $5 /-$ for the first child and 3/6d for subsequent children.

In taking up the cause of mothers, the inter-war organised feminist movement was deliberately allying itself with the long-standing concerns of women in the labour movement. Eleanor Rathbone condemned what she viewed as the selfishness of middle class women, who, having got 'all they wanted for themselves out of the women's movement when it gave them the vote, the right to stand for Parliament and the local authorities, and to enter the learned professions' sat back (33). On the one hand, a significant number of leading feminists, Millicent Garrett Fawcett among them, could not accept Rathbone's new vision of equality. Adhering to a nineteenth century classical liberal view of rights for women, they believed that women should confine themselves to campaigning for strict equality with men and agreed with policymakers that family allowances would likely destroy parental responsibility for children. On the other hand, in Rathbone's formulation, the demand for family allowances also ran the risk of antagonising the labour movement, or at least the men in it, because it threatened wage bargaining on the basis of men's demand for a family wage.

Thus the campaign for family allowances grew out of women's observations of working women's actual experience of family in the pre-war years and from a conscious reformulation of what equality meant for women in the immediate post-war years. Rathbone was asking fundamental questions about the position of women in relation to unpaid and paid work, and the division of resources within the family. Her analysis did not extend to questions of gender. If nineteenth century equalitarian feminists like Fawcett claimed equality for women on men's terms, Rathbone was content to settle for a species of 'separatism' and ask that 'women's work' be valued. She did not question the sexual division of labour in either paid or unpaid 
work: 'Women are the natural custodians of childhood. That at least is part of the traditional role assigned to us by men and one that we have never repudiated' (34). Thus while the post-war campaign for family allowances was not wholly in sympathy with the idea of a family wage, it did not go so far as to question the sexual divison of labour that accompanied it. Nor indeed did Rathbone feel that the relationship between marriage and motherhood should be called into question: the Family Endowment Committee and later the Family Endowment Council did not support the idea of paying family allowances to unmarried mothers.

THE FAMILY ALLOWANCES CAMPAIGN DURING THE INTER-WAR YEARS

In 1917, the Family Endowment Committee was comprised of seven members, four feminists from the NUSEC and three socialists. Membership expanded rapidly and in 1925 the Council became the Family Endowment Society with William Beveridge elected President and Rathbone vice-president. By this time the feminist voice had become both outnumbered (by fifteen to five) and submerged beneath numerous other groups who supported the principle of family allowances for very different reasons, and who advocated a variety of schemes for its implementation. Rathbone was unconcerned about this development, believing that mobilising commitment to the principle of family allowances was the most important role for the Family Endowment Society. Her own writing soon emphasised the problem of child poverty, about which most members of the society were concerned, rather than the economic independence of mothers. The society became sensitive to any suggestions, such as that by the Director of LSE in 1927, that the campaign for family allowances was infected by 'the taint of feminism' (35). In this instance an FES member was quick to point out that Sir Willim Beverdige was in favour of allowances and that he was not a feminist. Rathbone's major work on family allowances, The Disinherited Family, published in 1924, showed that the average family of five on which all previous calculations as to family poverty had been based, was atypical. Only $8.88^{\circ}$ of families had three children. Unmarried workers accounted for 278 of families, 24.78 consisted of a married couple with no 
child under fourteen, 16.68 had one child, 138 two, and 9.98 more than three. Furthermore, 40.48 of the child population was to be found in the 9.98 of families with more than three children which were also likely to be the poorest families. All subsequent social surveys of the $1930 \mathrm{~s}$ made a point of showing not only the percentage of families falling below the poverty line, but also the percentage of children, which was always greater. During the 1930s, the highly charged debate about the relationship between mass unemployment and nutrition levels was joined by activists in the campaign for family allowances, who formed the Children's Minimum Council and argued for a range of reforms from the raising of unemployment benefit rates to free milk for school children and nursing mothers and rent rebates, as well as family allowances (36).

While the humanitarian concern about child poverty was perhaps the strongest motivation within the movement for family allowances, another vocal source of support came from the Eugenics Society, which hoped family allowances would prove a solution to the population question. In the 1920s, eugenicists argued that if allowances were given only to the able it would be possible to create a 'true aristocracy' (37). Rathbone herself was not adverse to such arguments and saw merit in allowing the state to have its hand on the 'tiller of maternity' by varying the amount payable to each child and so manipulating the birth rate (38). One proposal from the Eugenics Society advocated payment of allowances only to families which had risen above 'the mean social level', defined as those with an income of L 500 or more (39). Socialists stood in direct opposition to this, advocating allowances for the poor to be financed out of taxation. Conservatives remained suspicious of the effect family allowances might have on the father's obligation to maintain until in 1937 the Report of the Unemployment Assistance Board showed that 68 of male wage earners were better off drawing unemployment benefits than when they were working. For the most part, these cases were ones 'in which the applicant has a low wage rate and a large family' (40). After 1937, Conservative opinion swung 
towards family allowances as a means of maintaining work incentives for men with large families and low wages.

Firms and institutions began experiments paying family allowances during the inter-war years. For example, under Beveridge's directorship, the LSE paid allowances in an effort to raise the birth rate among academic staff. By 1939, 20 firms, including Pilkingtons, Tootal's and Cadburys had adopted some system of allowances. L.J. Cadbury stated categorically that family allowances were 'a method of wage payment' (40). Indeed male trade unionists were correct in their early suspicions as to the way in which the relationship between family allowances and wages would be exploited by both government and employers. The FES had sought to persuade the Royal Commission on the coal Industry of the wisdom of paying family allowances to miners and thereby securing a living wage for those with large families without a general wage increase (42). The idea of family allowances as a part of or substitute for, wages was taken up again in World War II and has been shown by John Macnicol to have been the single most important factor prompting the passage of the Family Allowances Act (43). A memorandum submitted to the Treasury in 1938 assumed that it would not be possible to maintain wage rates at their pre-war level of purchasing power (44). In 1940, the House of Lords seized eagerly on allowances as means of breaking 'the vicious spiral of wages and prices' (45) and introduced two motions in 1941 and 1942 in support of a state system of family allowances.

When family allowances were introduced in 1945, they were paid only in respect of children after the first and at five shillings a week per child, a much lower rate than the eight shillings recommended by Beveridge in his 1942 Report on Social Insurance and Allied Services (46). Such a sum was not sufficient to provide a solution to the problem of child poverty, or an incentive to parenthood. Nor did it secure the economic independence of mothers and children. Only one small part of the original feminist proposal for allowances was achieved. The original Family Allowances Bill proposed to pay the allowance to the father. Rathbone warned that 'sex grievance' would 
play a large part in the next election if the clause were not changed. Her protests were successful and allowances were paid directly to women.

\section{MODELS OF EQUALITY}

Since 1945, two major issues have persisted in regard to the payment of family allowances, first whether they should be paid to the father rather than to the mother, and second and more broadly, how the purpose of family allowances should be defined and whether allowances should be paid selectively rather than to all families. Rathbone's position on the first issue was clear. She believed allowances should be paid to the mother, who took primary responsibility for her children's welfare, in order to reduce her economic dependence on her husband. This issue has been raised on two specific occasions since 1945. In 1977 the Labour government faltered in its resolve to merge family allowances and child tax credits into the new child benefit because of the transfer that would take place from male 'wallet' to female 'purse' (47). Male trade unionists were not keen to see men's tax advantage in respect to child tax credits disappear. More recently the Thatcher government's 1984-5 review of social security floated the idea of abolishing child benefit entirely and proposed to pay a new benefit for low waged families, family credit, through the male pay packet rather than through the post office where it is usually collected by women (48). The justifications for these changes have not been dissimilar from those underlying Ramsay MacDonald's objections to family allowances before World War I, viz. that there was no reason to suppose that working men would not provide for their wives and children.

In respect to the second issue of universality versus selectivity, from 1924 onwards the leading edge of the Family Endowment Society's argument was the need to reduce child poverty, but Rathbone was not inclined to target allowances selectively so that they went only to poor families, not least because she was as concerned about gender as class inequalities. Others, like Beveridge, supported the principle of universality chiefly out of a 
desire to avoid means testing. Today it has been suggested that the purposes of child support payments may be threefold: to secure greater vertical equity (that is to do something about child poverty); to secure greater horizontal equity (that is to support families with children); and to secure greater intra-family equity (to give mothers more financial resources as against fathers). It is possible to argue for greater selectivity as a means of advancing the first of the objectives, although the figures produced by Henwood and Wicks do not support it (49). Nevertheless, policy development has been and will be dependent on which objective is given priority. In fact, because they were introduced for the pragmatic reason of holding down wages, family allowances have never achieved the objectives of any lobby group, indeed their value has been substantially eroded since the late 1960 s.

From the point of view of achieving greater equality for women, policies that address the issue of how to care for and support children have as much power to break what Bruegel has called the 'vicious circle' (50) of inequality women find themselves in as they did when Rathbone first pointed out the implications of attaching a value to unpaid work both for the divison of resources within the family and for women's struggle for equal pay. Because women relate to a more complicated set of structures than do men, including reproduction as well as production, on the assumption of heterosexual coupling and no collective childcare women become trapped in certain segregated roles in both the labour market and the home. The assumption that those who bear children will also rear them results in an unequal division of domestic labour which must in turn be linked to (even if it is not the only cause of) women's unequal position in the labour market and economic dependency on men.

In its original formulation at the end of World War I, a policy for family allowances was intended only to attach value to women's unpaid work (much in the same way as the 1970 s campaign for wages for housework) and thereby decrease women's economic dependency on men and increase the chance 
of women receiving equal pay in the labour market. There was no intention of increasing women's leverage on the paid labour market, on the contrary married women's primary role as wives and mothers was accepted. Nor was there any intention of achieving a more equal division of paid and unpaid work. While post-World War I feminists recognised that nineteenth century 'fair field and no favour' feminism had sought equality on men's terms, their own attempt to redress the balance and achieve a 'real equality' for women was also sought on men's terms in that it addressed no challenge to the sexual division of labour whose terms were dictated by men. Both feminists and the child poverty lobby group were concerned to use family allowances as a means of redressing the balance of inequality. In the classic manner of liberal welfare reforms from the period of the Liberal Government of 1906-1914 to the present, the measure was inspired by concern to compensate and correct outcomes - to modify market forces in determining who gets what - without any attention being paid to the effects of such a policy in sustaining the unequal division of labour. This may be defended in terms of the way in which women in the early twentieth century seemingly shared the ideal of a family wage and, had no great wish to increase their burdens by engaging in regular paid employment. Although from women's point of view it was obviously problematic that the objective of redistribution in favour of children was given priority over intra-familial redistribution during the inter-war period.

Since World War II the material circumstances of adult women have changed dramatically. The labour participation rate of married women has increased from a relatively steady 108 between 1911 and 1931 to $62 \%$ in 1980 (some 408 of whom work part-time). This together with the decrease in the number of years spent in pregnancy and nursing (from 15 in the $1890 \mathrm{~s}$ to 4 in the post-war years) means that women's concerns are very different from the beginning of the early twentieth century and from the late 1960 s have focussed far more on their position in the labour market, the demand for equal pay and child care. The family wage has become no more of a reality and increasingly also a contested ideal. In this context, support for an 
increased rate of child benefit still has an important role to play in securing greater equality for women, but only if it is made part of a package designed to secure changes in the structures to which women relate such that a genuine equality of opportunity is created. Measures to correct inequality of outcome and attempts to achieve equality of opportunity by legislating only to provide individual redress of grievance are inadequate. Child benefits remain important to women because they are paid to women and thereby provide a sure source of income for women, who, even though they are likely to be earning are also likely to be in low paid, part time jobs. But equal opportunities fully to share paid and unpaid work and leisure must rest on a broader package of policies designed to get men to share unpaid work of household chores and caring (the most obvious being parental leaves) and also human service work in the labour market, whether in old peoples' homes or day care centres. Historical examination of the conceptualisation of equality for women helps us to see that genuine equality of opportunity can only be achieved by more of a focus on gender, rather than on women, and more attention not just to the relationship between benefits and welfare as conceptualised by Rathbone, but between benefits, work and welfare. 


\section{NOTES}

*This paper was presented at the European University Institute, Department of History and Civilization, in Gisela Bock's seminar on "Poverty, Family and Welfare: Maternity and Visions of Gender in Europe", in October 1986.

1. Charles Booth, London Life and Labour (London, 1889); B. Seebohm Rowntree, Poverty: a Study of Town Life (London, 1913); and Peter Townsend, Poverty in the UK (Harmondsworth, 1979).

2. K.D. Courtney et al., Equal Pay and the Family (London, 1918).

3. John Macnicol, The Movement for Family Allowances (London, 1980).

4. Anna Coote, 'The AES: a new starting point', New Socialist, Nov/Dec., 1981.

5. Elizabeth Fee, 'Science and the Woman Problem: historical perspectives', in M.s. Teitlebaum (ed.), Sex Differences: social and biological perspectives (Garden City, 1976).

6. Cicely Hamilton, Marriage as a Trade (London, 1909).

7. Elizabeth Roberts, A Woman's Place (Oxford, 1984).

8. Helen Bosanquet, The Family (London, 1906).

9. Cited by Pat Thane, 'The Working Class and State "Welfare" in Britain, 1880-1914', Historical Journal 27 (1984).

10. Jane Lewis, The Politics of Motherhood (London, 1980), p. 44. 
11. Henry Higgs, 'Workmen's Budgets', Journal of the Royal Statistical Society 56 (1893).

12. Booth, London Life and Labour, Vol. I.

13. M. Llewellyn Davies, Maternity: letters from working women (London, 1915).

14. Ellen Ross, "Fierce Questions and Taunts": married life in working class London, 1870-1914', Feminist Studies 8 (1982).

15. John Burnett, Destiny Obscure. Autobiographies of Childhood, Education and Family from the 1820 s to the 1920s (London, 1982), p. 258 .

16. Nancy Tomes, "A Torrent of Abuse": crimes of violence between working class men and women in London, 1840-1875', Journal of Social History 11 (1978); and Pat Ayers and Jan Lambertz, 'Marriage Relations, Money and Domestic Violence in Working Class Liverpool, 1919-39', in Jane Lewis, ed., Labour and Love (Oxford, 1986).

17. Roberts, A Woman's Place.

18. Mrs. J.R. MacDonald et al., Wage Earning Mothers (London, nd.)

19. WIC, Memo on the National Insurance Bill as it affects Women (TS, 1911, BLPES).

20. Magdalen Stuart Pember Reeves, Round about a Pound a Week (London, 1913).

21. Anna Martin, Married Working Women (London, 1911).

22. Ibid., pp. 36-7. 
23. Ibid., pp. 29-30.

24. See especially Ross, 'Fierce Questions and Taunts"', and Roberts, $\underline{A}$ Woman's Place.

25. Jan Pahl, Marriage and Money (London, forthcoming).

26. Mrs. Bernard Shaw (ed.), Summary of Eighty Papers and Discussions upon the Disabilities of Mothers and Workers (London, 1910), p. 5 .

27. Quoted by Hilary Land, 'The Family Wage', Feminist Review 6 (1980).

28. Local Government Board, Mothers Pensions in the USA (London, 1918).

29. Eleanor Rathbone, 'The Remuneration of Women's Services', The Economic Journal 27 (1917).

30. J.M. Winter, 'Aspects of the Impact of the First World War on Infant Mortality in Britain', Journal of European Economic History 11 (1982).

31. Women's Leader, $17 / 7 / 25$, p. 145 .

32. Mary Stocks, The Case for Family Endowment (London, 1927), p. 10.

33. Eleanor Rathbone, Milestones: presidential addresses at the Annual Council Meetings of the NUSEC (London, 1929), p. 8.

34. Ibid., p. 4 .

35. The Times, $17 / 10 / 27$, p. 16 .

36. Lewis, Politics of Motherhood, pp. 181-6. 
37. C.W. Armstrong, the Only Way. A Suggestion to the True Solution of the Problems of Population (London, 1921), p. 11 .

38. Eleanor Rathbone, The Disinherited Family (London, 1924), p. 247.

39. William McDougall, National Welfare and National Decay (London, 1921), pp. $196-7$.

40. PP. 1937-8, Vol. XIII, Cmd 5752, The Report of the UAB for the year ending $31 / 12 / 37$, p. 82 .

41. The Times $6 / 1 / 40$, p. 4 .

42. Eleanor Rathbone, Memo of Evidence on Behalf of the FES to the Royal Commission on the Coal Industry, 1925 (London, 1925), p. 4.

43. Macnicol, Movement for Family Allowances.

44. PRO, T161/1116, Memo on Wages and the Cost of Living, $30 / 11 / 39$.

45. PP. (Lords) 115 (1940), cols. 648-49.

46. PP. 1942-3, Vol. VI, Cmd. 6404, Report on Social Insurance and Allied Services, 1942 .

47. Hilary Land, 'The Child Benefit Fiasco', in K. Jones (ed.), The Yearbook on Social Policy (London, 1976).

48. Hilary Land, Women Won't Benefit (London, 1986).

49. Melanie Henwood and Malcolm Wicks, Benefit or Burden? The objectives and impact of child support, Family Policy Studies Centre, Occasional Paper No. 3 (London, 1986). 
50. Irene Bruegel, "Women's Employment, Legislation and the Labour Market", in Jane Lewis, Women's Welfare/Women's Rights (London: Croom Helm, $1983)$, p. 158 . 


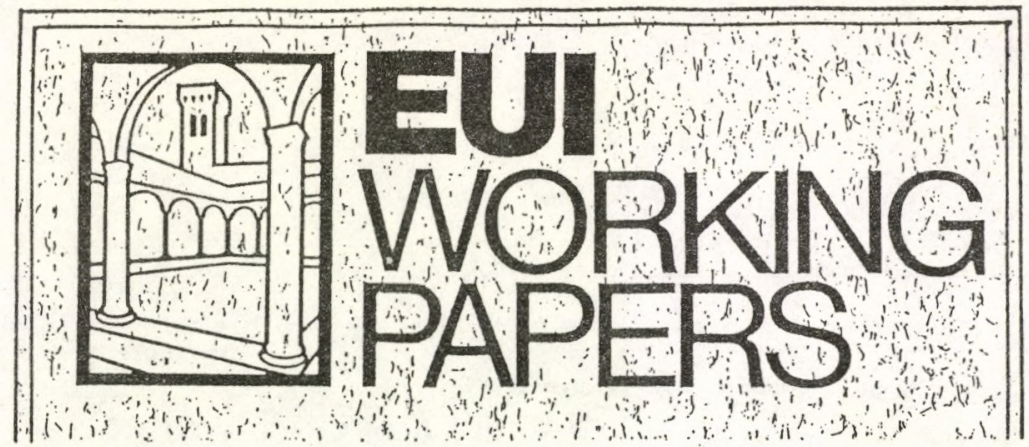

EUI Working Papers are published and distributed by the European University Institute, Florence.

A complete list and copies of Working Papers can be obtained free of charge -- depending on the availability of stocks -- from:

The Publications officer

European University Institute

Badia Fiesolana

I-50016 San Domenico di Fiesole (FI)

Italy

Please use order form overleaf 
PUBLICATIONS OF THE EUROPEAN UNIVERSITY INSTITUTE

To

The Publications officer

European University Institute

Badia Fiesolana

I-50016 San Domenico di Fiesole (FI)

Italy

From

Name.

Address

Please send me:

a complete lịt of EUI Working Papers

the following EUI Working Paper(s):

No.

Author, title:

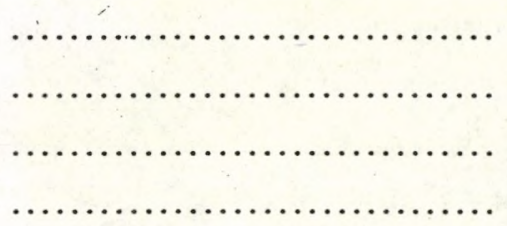

Date:........... 
87/271: Winfried BOECKEN

87/272: Serge NOIRET

87/273: Gisela BOCK

87/274: Jean BLONDEL

87/275: Birgitta NEDELMANN

87/276: Paul MARER

87/277: Felix FITZROY

87/278: Bernd MARIN

87/279: Darrell DUFFIE and Wayne SHAFER

87/280: Martin SHUBIK

87/281: Goesta ESPING ANDERSEN

87/282: Neil KAY
Der verfassungsrechtliche Schutz von Altersrentenansprüchen und -anwartschaften in Italien und in der Bundesrepublik Deutschland sowie deren Schutz im Rahmen der Europäischen Menschenrechtskonvention

Aux origines de la reprise des relations entre Rome et Moscou. Idéalisme maximaliste et réalisme bolchevique:

la mission Bombacci - Cabrini à Copenhague en avril 1920.

Geschichte, Frauengeschichte, Geschlechtergeschichte

Ministerial Careers and the Nature of Parliamentary Government:

The Cases of Austria and Belgium

Individuals and Parties - Changes in Processes of Political Mobilization *

Can Joint Ventures in Hungary Serve as a "Bridge" to the CMEA Market?

Efficiency Wage Contracts, Unemployment and Worksharing

Contracting Without Contracts Economic Policy Concertation by Autopoietic Regimes beyond Law

Equilibirum and the Role of the Firm in Incomplete Markets

A Game Theoretic Approach to the Theory of Money and Financial Institutions

State and Market in the Formation of Social Security Regimes A Political Economy Approach

Markets and False Hierarchies: Some Problems in Transaction Cost Economics 
87/283: Leslie OXLEY and Donald GEORGE

87/284: Saul ESTRIN and Derek JONES

87/285: Domenico Mario NUTI

87/286: Felix FITZROY

87/287: Paul HARE

87/288: Roberto TAMBORINI

87/289: Corrado BENASSI

87/290: Johan BARNARD

87/291: Gisela BOCK

87/292: Frank PROCHASKA

87/293: Karen OFFEN

87/294: Gunther TEUBNER

87/295: Luciano BARDI.

87/296: Gianna GIANNELLI

87/297: Domenica TROPEANO

87/298: B. THOM, M. BLOM

T. VAN DEN BERG,

C. STERK, C. KAPLAN
Perfect Foresight, Non-Linearity and Hyperinflation

The Determinants of Workers' Participation and Productivity in Producer Cooperatives

Financial Innovation under Market Socialism

Unemployment and the Share Economy: A Sceptical Note

Supply Multipliers in a Centrally Planned Economy with a Private Sector

The Stock Approach to the Exchange Rate: an Exposition and a Critical Appraisal

Asymmetric Information and Financial Markets: from Financial Intermediation to Credit Rationing

The European Parliament and Article 173 of the EEC Treaty

History, Women's History, Gender History

A Mother's Country: Mothers' Meetings and Family Welfare in Britain, 1850 1950

Women and the Politics of Motherhood in France, 1920 - 1940

Enterprise Corporatism

Preference Voting and Intra-Party Competition in Euro-Elections

On Labour Market Theories

The Riddle of Foreign Exchanges: A Swedish-German Debate

Pathways to Drug Abuse Amongst Girls in Britain and Holland 
87/299: V. MAQUIEIRA, J.C. LAGREE, P. LEW FAI, M. De WAAL

87/300: A. ELZINGA, P. NABER, R. CIPPOLLINI,

F. FACCIOLI, T. PITCH

87/301: S. LEES, J. SHAW, K. REISBY

87/302: Eleanor MILLER, Rosa ANDRIEU-SANZ and Carmen VAZQUEZ ANTON

87/303: Mary EATON and Lode WALGRAVE

87/304: Annie HUDSON Edna OPPENHEIMER

87/305: Talman VAN DER LAN

87/306: Paolo C. GARELLA

87/307: Jean-Michel GRANDMONT

87/308: Birgit GRODAL/Werner HILDENBRAND

87/309: Eric PEREE/Alfred STEINHERR

87/310: Giampaolo VALDEVIT

87/311: Federico ROMERO

87/312: Pietro REICHLIN

87/313: Neil KAY, Jean-Philippe ROBE and Patrizia ZAGNOLI
Teenage Lifestyles and Criminality

in Spain, France and Holland

Decision-Making About Girls by the Criminal Justice System in Holland and Italy

Aspects of School Culture and the Social Control of Girls

Becoming a Teenage prostitute in Spain and the U.S.A.

A comparison of crime and its treatment amongst girls in Britain and Belgium

Towards an effective policy for delinquent girls

Computing, Economic Equilibria

Adverse Selection and Intermediation

Local Bifurcations and Stationary Sunspots

Income Distributions and the Axiom of Revealed Preference

Exchange Rate Uncertainty and Foreign Trade

American Policy in the Mediterranean: The Operational Codes, 1945-1952

United States Policy for Postwar European Reconstruction: The Role of American Trade Unions

Output-Inflation Cycles in an Economy with staggered wage setting

An Approach to the Analysis of Joint Ventures 
87/314: Jane LEWIS

87/315: Serge NOIRET

87/316: Alain GoussoT

87/317: Eamonn NOONAN

87/318: Jean/Pierre CAVAILLE'
Models of Equality for Women: The Case of State Support for Children in 20th Century Britain

Perchè studiare i meccanismi delle leggi elettorali in Italia. Una riflessione metodologica a proposito della legge del 1919.

Les' sources internationales de la culture socialiste italienne à la fin du $19 \mathrm{e}$ siècle et au début du $20 \mathrm{e}$ siècle. Problèmes de la composition de l'idéologie du PSI et ses rapports avec la circulation des idées en Europe

Württtemberg's exporters and German protection, 1931-36

Teatrum Mundi. Notes sur la théâtralité du Monde Baroque. 